University of Nebraska - Lincoln

DigitalCommons@University of Nebraska - Lincoln

Faculty Publications from the Harold W. Manter Laboratory of Parasitology

1972

\title{
PARASITES OF NEBRASKA PHEASANTS
}

Ellis C. Greiner

University of Nebraska State Museum

Follow this and additional works at: https://digitalcommons.unl.edu/parasitologyfacpubs

Part of the Parasitology Commons

Greiner, Ellis C., "PARASITES OF NEBRASKA PHEASANTS" (1972). Faculty Publications from the Harold W. Manter Laboratory of Parasitology. 650.

https://digitalcommons.unl.edu/parasitologyfacpubs/650

This Article is brought to you for free and open access by the Parasitology, Harold W. Manter Laboratory of at DigitalCommons@University of Nebraska - Lincoln. It has been accepted for inclusion in Faculty Publications from the Harold W. Manter Laboratory of Parasitology by an authorized administrator of DigitalCommons@University of Nebraska - Lincoln. 


\section{PARASITES OF NEBRASKA PHEASANTS}

ELLIS C. GREINER, The Harold W. Manter Laboratory of Parasitology,

University of Nebraska State Museum, Lincoln, Nebraska 68508, U.S.A.

Alstract: Parasite prevalence, intensity, and diversity in Nebraska pheasants (Phasianus colchicus) were studied during the fall of 1971 . Fifty-four of $63(86 \%)$ pheasants examined for helminths harbored at least one parasite species. Heterakis gallinarum $165 \%$ of the pheasants), Choanotaenia infundibulum (48\%). Echinoparyphium recurratum (1.6\%), and Zygocotyle lunata (1.6\%) were recovered. Two of $15(13 \%)$ birds examined for coccidia possessed Eimeria phasiani. None of 35 pheasants examined for hematozoa had patent infections. 


\section{INTRODUCTION}

Parasite prevalence, intensity, and diversity in healthy host populations must be known before the influence of parasitism can be properly assessed following a wildlife die-off. These factors were studied by utilizing hunter-killed pheasants.

\section{METHODS AND MATERIALS}

Complete digestive tracts, livers, gall bladders and tracheae were collected during November, 1971, from pheasants at check stations in Box Butte, Lincoln, Clay, and Lancaster Counties (Fig. 1). All viscera were frozen until necropsy. Guts were slit longitudinally and contents were washed into sedimentation flasks, decanted and viewed under a dissecting microscope for helminths. Tracheae and gall bladders were slit open and livers were externally examined. Helminths recovered were processed and identified by standard helminthological procedures.

Fecal samples were removed from intestines prior to their freezing and were placed in $2.5 \%$ potassium dichromate solution for coccidial examination. These cultures were examined for oocysts 2-3 weeks later.

Blood smears were made during September and October, 1971, from pheasants in Clay, Lancaster, Perkins, Phelps, Sherman, and Thurston Counties (Fig. 1 ). Smears were stained with Hewitt's Giemsa.

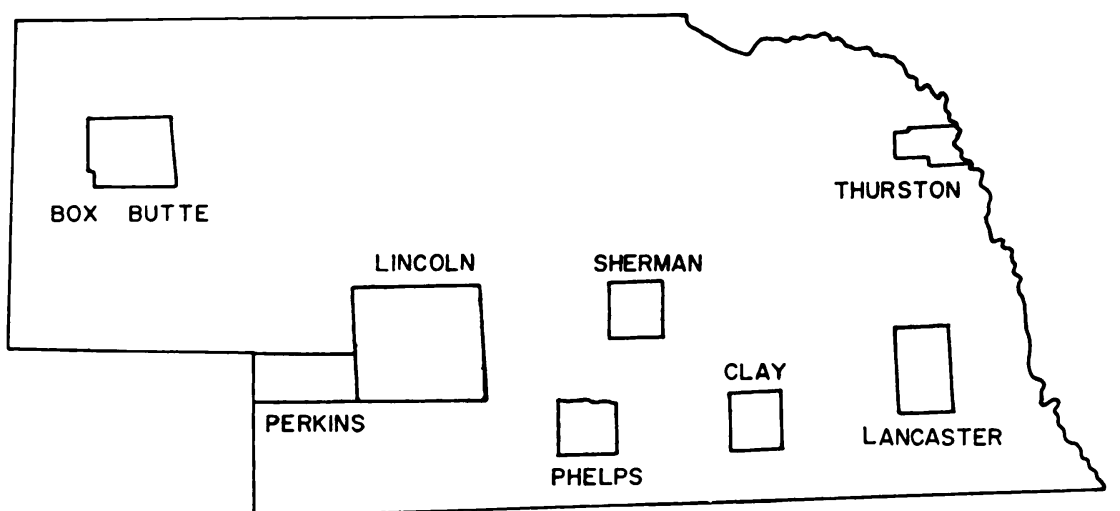

FIGURE 1. Counties from which pheasants were sampled.

\section{RESULTS AND DISCUSSION}

Table 1 summarizes the parasite prevalence and intensity in Nebraska pheasants. At least one parasite species was found in 54 of $63(86 \%)$ birds.

The absence of haemosporidians in Nebraska pheasants (Table 1 ) is consistent with present literature. I find no record of natural haemosporidian infection from North American pheasants. Jordan" suggested that an innate immunity protected pheasant chicks against Plasmodium lophurae, a species which is highly virulent and lacks host specificity. The same immunity may also explain the lack of other haemosporidian infections in pheasants.

Eimeria phasiani was found in 2 of 15 (13\%) pheasants. Olsen ${ }^{5}$ observed this species in $1.3 \%$ of the Minnesota pheasants surveyed and Ormsbee ${ }^{\beta}$ found at least one species of Eimeria in $40 \%$ of the pheasants examined from Washington.

Olsen ${ }^{5}$ reported Echinoparyphium recurvatum and E. contiguum from Minnesota pheasants. A single specimen of $E$. recurvatum, one immature echinostome possessing 32 collar spines, and one Zygocotyle lunata were recovered in the present study. The latter species is normally 


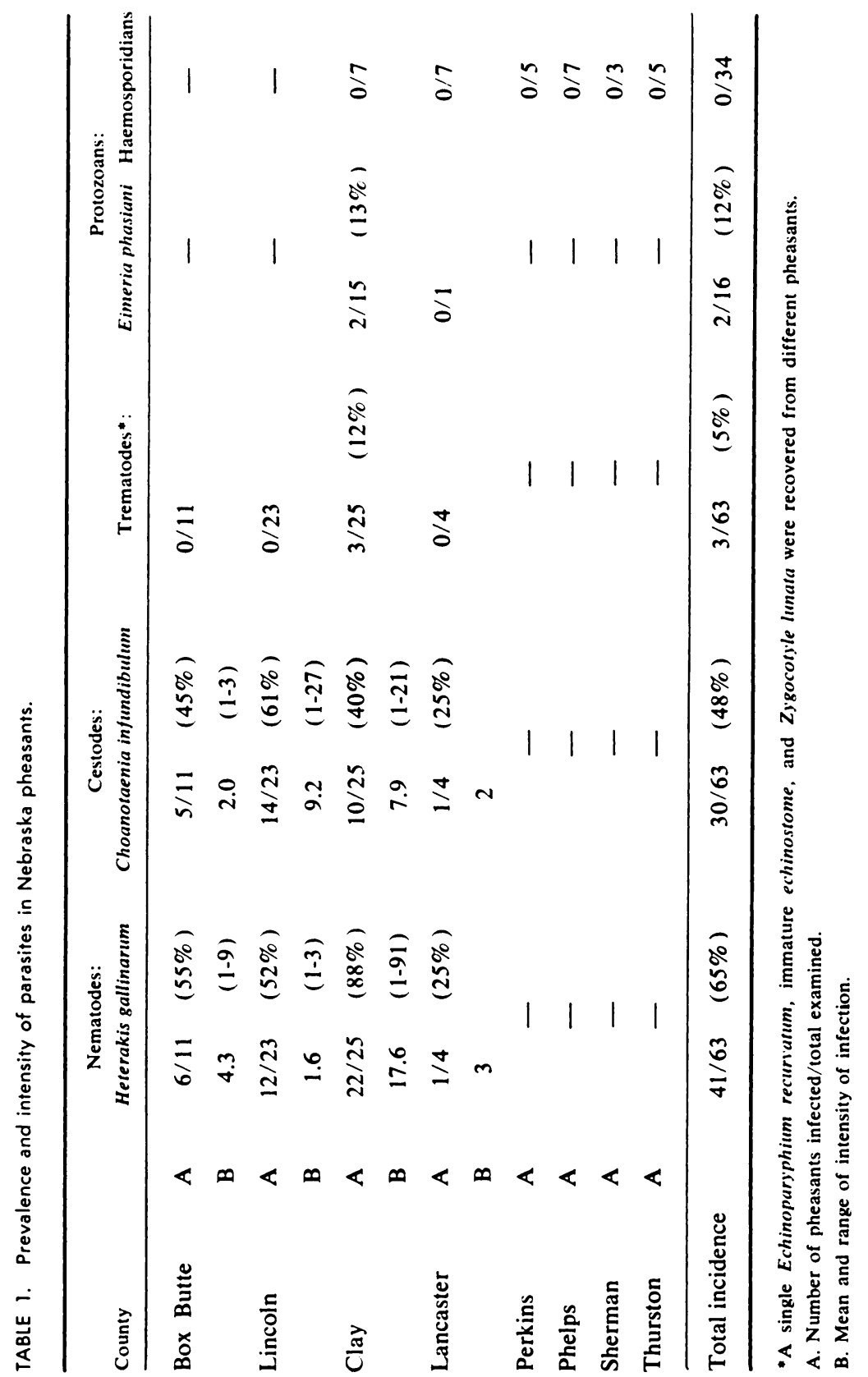


a cecal fluke of chickens, ducks, and geese' and is reported here from a pheasant for the first time.

The prevalence of Choanotaenia infundibulum in Nebraska pheasants $(\mathbf{4 8 \%})$ was higher than in those surveyed in South Dakota $(5.7 \%)^{2}$ and Minnesota $(7.5 \%) .5$ When recovered, most of the cestodes possessed only scoleces with a few immature proglottids attached. Terminal proglottids were usually not rounded posteriorly, indicating possible destrobilation rather than recent acquisition. Gilbertson and Hugghins ${ }^{2}$ observed an absence of $C$. infundibulum in South Dakota pheasants during January and February, although this cestode was present in their fall and spring samples. Possibly the pheasants in the current study were in the process of losing their cestodes.
There was a higher prevalence of Heterakis gallinarum in Nebraska pheasants $(65 \%)$ than in those of South Dakota $(35 \%)^{2}$, Illinois $(46 \%)^{4}$, and Minnesota $(51 \%) .^{\circ}$ Nebraska Game and Parks Commission estimates of pheasant populations list Clay County as nearly five times more concentrated than Lincoln County. Box Butte and Lancaster Counties are intermediate. Heterakis gallinarum prevalence and intensity were higher in Clay County than in Lincoln County (Table 1). Since $H$. gallinarum has a direct life cycle, finding a correlation between host population density and parasite prevalence and intensity was not surprising.

Eimeria phasiani (Coccidia), Echinoparyphium recurvatum and Zygocotyle lunata (Trematoda), and Choanotaenia infundibulum (Cestoidea) supplement the checklist of Becklund.'

\section{Acknowledgement}

The author wishes to thank Mr. William Baxter, Nebraska Game and Parks Commission, for making the blood smears and arranging for collection of pheasant viscera.

\section{LITERATURE CITED}

1. BECKLUND, W. W. 1964. Revised check list of internal and external parasites of domestic animals in the United States and Possessions and Canada. Am. J. Vet. Res. 25: 1380-1416.

2. GILBERTSON, D. E., and E. J. HUGGHINS. 1964. Helminth infections in pheasants from Brown County, South Dakota. J. Wildl. Mgmt. 28: 543-546.

3. JORDAN, H. B. 1957. Host resistance and regulation of the development of Plasmodium lophurae in pheasants, coots, and domestic pigeons. J. Parasit. 43: 395-408.

4. LEIGH, W. H. 1940. Preliminary studies on parasites of upland game birds and fur-bearing mammals in Illinois. Ill. Nat. Hist. Survey Bull. 21 (5): 185-194.

5. OLSEN, O. W. 1938. Parasite studies on ring-necked pheasants, Phasianus colchicus torquatus, in Minnesota. J. Parasit. 24 (suppl) : 24-25.

6. ORMSBEE, R. A. 1939. Field studies on coccidiosis in the ring-necked pheasants in eastern Washington. Parasitology 31: 389-399. 